\title{
An Assessment of the Methods of Development in the Essays of Business Students in Ghanaian Private Universities: A Case Study
}

\author{
Asuamah Adade-Yeboah1, Edward Owusu ${ }^{2 *}$ \\ ${ }^{i}$ Department of Communication Studies, Christian Service University College, Kumasi, Ghana \\ ${ }^{2}$ Department of Communication Studies, Sunyani Technical University, Sunyani, Ghana \\ Email: ^edwardowusu@minister.com
}

How to cite this paper: Adade-Yeboah, A. and Owusu, E. (2016) An Assessment of the Methods of Development in the Essays of Business Students in Ghanaian Private Universities: A Case Study. Open Access Library Journal, 3: e3176.

http://dx.doi.org/10.4236/oalib.1103176

Received: October 27, 2016

Accepted: November 28, 2016

Published: December 1, 2016

Copyright $\odot 2016$ by authors and Open Access Library Inc.

This work is licensed under the Creative Commons Attribution International License (CC BY 4.0).

http://creativecommons.org/licenses/by/4.0/

\section{(c) (i) Open Access}

\begin{abstract}
The study is an attempt to assess the methods of development in the compositions of students who are reading various business-oriented courses in private universities in Ghana. This area has received little attention from researchers in Ghana. Two private universities-Christian Service and Ghana Baptist University College-were the two selected cases. Prior investigations exposed students' writing flaws in the form of wrong usage of the features of a particular method of development when writing essays. Therefore, the literature reviewed was mostly based on these gaps indicated. The primary data collected from the field were from texts (classroom-based and take-home-based texts). Basically, probability sampling techniques were employed to sample the population of the cases selected. All the data gathered were descriptively analysed. The findings showed that students have problems composing descriptive and comparison and contrast paragraphs or essays. But, the study brought to light that students handled narrative, argumentative, and cause and effect essays knowledgeably. It was recommended that enough attention should be given to the teaching and learning of descriptive and comparison and contrast essays. It is our expectation that the findings and recommendations of the work would influence the decisions of policy makers in the field of English language.
\end{abstract}

\section{Subject Areas}

Education

\section{Keywords}

Methods of Development, Essays, Descriptive, Narrative, Argumentative Essays, Analogy 


\section{Introduction}

Language is a key issue in our existence. English is one of the most widely used languages. In Ghana, it plays an important role since it is the medium of instruction and the official language. The teaching and learning of English can help the students to deal successfully with their academic demands and to perform successfully in their disciplines and professional context [1]. Thus, within the context of an environment where English is the language spoken, the academic and professional success of students to a large extent depends on their ability to use the language effectively. Basically, the teaching and learning of English writing (or Composition/Essay) at the business departments of most private universities in Ghana is captured by courses such as Business Communication, Communication Skills I and II, and English Language I and II; and it is incumbent on the lecturer concerned to take the students through the rudiments of business write-ups such as memoranda, reports, letters, proposals and other write-ups within students' purview.

A good number of students studying at the business departments of privately-owned universities in Ghana are people who either occupy key managerial positions in the business world or desire to fill certain managerial positions in the world of commerce on completion of their study. Hence, it is vital that essay writing and the writing of other business correspondence are taken seriously by both the students and the lecturer.

In academic context, students are required to produce specific genres such as, essay, summary, critical review and research paper [1] [2]. The point is, in developing an idea, in a given situation, certain conventions are expected to be observed. These conventions facilitate listening and reading comprehension if strictly complied with. They help the reader or the listener to follow the message being put across.

On the contrary, a lot of students in the business departments of private universities in Ghana take some of these conventions for granted. This issue could be attributed to the fact that they are either oblivious of the rubrics of composition or they simply do not get the right guidance. This work is therefore, an attempt to describe and account for some of the writing or composition shortcomings of business students who are studying in privately-owned universities in Ghana [3].

\section{Literature Review}

Methods of Development refers to the methods a writer has used in developing ideas in his or her essay. The prominent methods of development include: Narrative, Illustration/Exemplification, Description, Comparison and Contrast, Division/Classification, Cause and Effect, Process Analysis, Definition, Analogy, and Argumentative/Persuasive Writing:

\subsection{Narration}

"Narration is storytelling, whether we are relating a single story or several related ones" [4]. Through narration, we make a statement clear by relating in detail something that 
has happened to us [4]. Thus, through the act of narration, we are able to tell our experiences to people in a story form. According to [5] one of the things that defines us as human is the universal desire and ability to create narrative. Consequently, there seems to be a kind of correlation between humanity and narration; in that every person, consciously or subconsciously exhibits this act at a point in time. [6] posit that a short story is a brief, creative narrative-a retelling of events arranged to hold a reader's attention. Whether the story is short or long, there are certain elements-setting, characters, dialogue, plot, suspense, and events in time-that are characteristic of every narrative piece. Without these constituents, one would find it problematic telling a story.

\subsection{Description}

The descriptive act calls on the writer to pay particular attention to the five sensessight, sound, smell, touch, and taste. Appealing to the senses is important in descriptive work; in that the writer has to show rather than tell the entity being described [4] [5] [6] [7] [8]. Consequently, this has been a convention in descriptive essays-show don't tell-and for one to show effectively, one has to appeal to the senses. For example, rather than say, "the room was dirty" the writer could say "... it was as if the room served as an abode for filth." As telling, is an element of narration, showing has to do with description... therefore, an extensive amount of telling in descriptive essay, will amount to a deviation of the method of development used. Adjectives, adverbs and figurative expressions are highly employed in descriptive work. According to Anderson et al. [9] description creates a mood and emotion. When the writer uses several adjectives and adverbs to describe a phenomenon, the reader's or listener's emotions are aroused.

\subsection{Comparison and Contrast}

Another method of development is Comparison and Contrast. Every day of our lives we do compare and contrast things. We always compare and contrast goods when we go to the shopping mall. The mind does this, so that it could select the product it wants. Therefore, [8] have argued that it is part of the design of the mind; it is an action that is a natural mental process. This kind of essay invariably requires one to show the relationship that exists between two things in terms of parity and disparity. The two main methods used in writing comparison and contrast essays or paragraphs are: point-bypoint and subject-by-subject [4] [5] [6] [8] [10] [11] [12] [13]. These methods enable the reader to organize his thoughts well.

\subsection{Cause and Effect}

[8] opine that "cause and effect analysis may be used to explain the reasons why things are, the way they are; to identify and explain effects or consequences of an event, action, decision, discovery, or invention; and to explain other causes and effects together." [5] on their part see it as "a tool by which we reflect upon and learn from our past..." [6] have also maintained that it is one of the expository writings that focus on the reasons why something happens or the results an event or situation will produce. To [4] "by 
examining the causes or effects of an action, we seek to understand and explain things that happen in our lives."

\subsection{Argumentative and Persuasive Writing}

Academia is characterized by mature reasoning. According to [14] academic argument has to do with understanding opposing positions as well as expressing our own positions; this therefore pushes opponents to engage in analysis. Academic argument, thus, has to do with one trying to fathom the views of opponents on a subject matter being discussed; and also articulating their own views on the issues at stake. This demands critical thinking and a detailed examination of the subject matter. To [5] argument is a rhetorical technique used to support or deny a proposition by offering detailed evidence for or against it in a logically connected fashion. To them, Classical argument relies on deductive and inductive thinking which appeals to reason alone [5].

\subsection{Analogy}

Some writers (for example, [4] [6] [8]) who have done comprehensive study on the various methods of development have failed to provide us with information on "analogy." This probably could be that by nature "analogy" and "comparison and contrast" as methods of development are interrelated. An analogy is a comparison made between two things to show how they are alike [9]. Thus, the term deals with comparison of entities in order to bring out their semblance and divergence. This notion is not different in paragraphing and essay writing as a whole. Analogies take the form of well-developed comparisons that reveal particular similarities between members of the same or different classes [5]. In consequence, [5] think that analogy, as a writing tool is basically employed to confirm the correlation between two things. This correlation could either be on the similarities or on the differences; and this marks the point of divergence for "analogy" and "comparison and contrast" essays.

\subsection{Division/Classification}

This method of development is an attempt to explain the nature and connections between bits of information that may, at first, seem unrelated and confusing [5]. Thus, writers often find it useful to identify like qualities or characteristics among various facts, ideas, people, or things so as to create related categories or classes by which the material can be divided logically and discussed systematically [5]. Furthermore, [5] think division/classification essays can be used to explain stages in human development as in Gail Sheehy's "Predictable Crises of Adulthood," to discuss current thinking about morality as in Meg Greenfield's "Why Nothing is "Wrong" Anymore," or to define one's ethnic, cultural, and sexual identity as in Kesaya E. Noda's "Growing Up Asian in America." It can help us analyse and understand the processes and motivations behind the way we read, think, and comprehend. Classification, thus, can be used to draw a line among units that are closely related. It is an act that our brains constantly perform willfully or subconsciously. And this makes it a natural process [8]. 


\subsection{Definition}

Definitions, in general, fall into three broad categories: lexical, "stipulative", and extended [5]. Lexical definitions are what we receive when we familiarise ourselves with new concepts in the dictionary; but, these definitions are sometimes abstract since the explanations given are sometimes without reference to particular contexts. "Stipulative" definitions, which are practical, are by their very nature limited to special purposes [5]. For example, when writing an article, one could inform their readers that, for the purposes of the paper, "a part-timer is someone enrolled for less than 2 credits" [5]. The part-time definition, in this context would be "stipulative." The extended definitions are those used to explain complex topics. They are the explanations that we formulate from a definition. We also have denotational and connotational definitions [8]. While denotation is the dictionary definition, connotation includes other implications. Therefore, in defining entities or topics or keywords in essays, we can be definitive (use an explanation from a source, especially the dictionary) and suggestive (use the figurative or indicative meaning) at the same time.

\subsection{Process Analysis}

Process Analysis is also a way of developing ideas in a paragraph or a complete discourse. Process analysis is a "how-to" Essay. It is a step-by-step way of executing a course of action [5] [6] [8]. Analyzing or breaking down a process step by step helps explain how something has been, or can be accomplished [8]. It is a way of explaining how something happens or happened [5]. Every day we perform many activities that are made up of processes. They include: making an omelet; fixing a flat car tyre; writing a research proposal; making a popcorn; diapering a baby; taking someone's temperature; and driving a car. The central feature of process analysis therefore is chronological sequence. Without it, the explanation would be chaotically done. In presenting a process in a sequential order, every paragraph should discuss an idea; and it is also palpable that transitional markers play pivotal role so that the reader or the listener might not lose focus on the chronology of activities presented [5] [6] [8].

\subsection{Illustration/Exemplification}

Illustration/Exemplification is also another method that one can use to develop a paragraph. Illustration (sometimes called exemplification) is a method of development or analysis useful for explaining and understanding things [8]. In our daily lives we always try to provide details or specific instances of information we give to people. It is a natural habit of the mind [5]. Thus, it is something that the mind subconsciously does. Illustration, therefore, provides an opportunity for a writer or speaker to provide specific cases or evidences to substantiate a claim made. Without it, our expressions become unclear and general. So, "effective illustrations make possible the explanation of ideas that might otherwise remain vague" [5]. Illustration or exemplification consequently, is a way of providing supporting concrete cases to back the statements we make so as to ensure that our statements are devoid of ambiguities. 


\section{Research Methods}

\subsection{Participants}

The participants of the study were 30 business students drawn from the two prominent private universities in Kumasi, Ghana. The students were at levels 100 and 200 as at the time data was collected (2011/2012 academic year). Their ages ranged between 19 and 32 with an average age of 25.18 of the participants were males, while the remaining 12 were females. 20 of the participants were from Christian Service University College (CSUC) and the remaining 10 were taken from Ghana Baptist University College (GBUC).

\subsection{Instruments}

This work focuses on five of the methods of development that are commonly taught as full essays in most Ghanaian schools. Data were obtained from classroom-based and take-home essay questions on the selected methods of development or essays (these are: narrative, cause and effect, description, comparison and contrast, and argumentative essays). 30 Classroom-based essay questions on narrative paragraphing and cause and effect essays were collected from CSUC and GBUC correspondingly. 12 take-home essay questions on the other methods of development (i.e. description, comparison and contrast, and argumentative) were also collected from level 100 and 200 students of both Institutions.

\subsection{Sample and Sampling Technique}

\subsubsection{Sampling Techniques for the Classroom-Based Texts}

Probability sampling techniques were used in selecting the cases needed. The classroom based texts were sampled from End-of-First Semester Examination (2011/2012 academic year) scripts of level 200 students of Christian Service University College (CSUC); and Mid-Semester Examination scripts of level 100 students (January 2012 session) of Ghana Baptist University College (GBUC). In sampling the class-room based text from each Institution, the class lists (sampling frame) were taken from the HODs. Because of the large numbers (150 students) in the sampling frame from CSUC, initially systematic random sampling (on a fraction of 1/10) was used to select 20 scripts out of the 150 end-of-first semester examination scripts. In the case of GBUC, because the cases (scripts) were relatively small in number (40 scripts), simple random sampling technique was employed to select 10 classroom-based scripts (mid-semester examination scripts).

\subsubsection{Sampling Techniques for the Take-Home Based Texts}

Here, the researchers composed 3 different take-home questions on Argumentative, Descriptive, and Comparison and Contrast essays. These essay-type essays or methods of development were chosen taking into consideration, the fact that the classroombased texts from CSUC and GBUC were on Narrative and Cause and Effect respectively. In each of the two Institutions, the students whose class-room based essay were selected, were implored to answer one take-home essay question (within a 7-day period) 
on different topics of Argumentative, Descriptive and Comparison and Contrast. These different essay questions were given to them randomly. After the one week period, the scripts from the two University Colleges were each stratified into three different strata: Argumentative, Descriptive and Comparison and Contrast essays. For CSUC, simple random sampling technique was used to sample 6 scripts (consisting of 2 scripts) from each major stratum of Argumentative, Descriptive and Comparison and Contrast essays. For GBUC, the same technique (simple random sampling) was employed to sample 6 scripts from each major strata mentioned above. In effect, a total of 30 classroombased texts and 12 take-home texts were used for the study.

\section{Methods of Data Analysis}

The data (scripts) were descriptively analysed. An analytical framework was used in analyzing the scripts. The variables used in the framework are context (5\%), organisation (5\%), expression (5\%), and mechanical accuracy (5\%). Overall, all the scripts were graded over $20 \%$.

\section{Results of Findings}

The findings on the competence level of students in terms of employing the elements of narrative, descriptive, cause and effect, argumentative and comparison and contrast essays are demonstrated below:

On narrative essays, it came to light that students have control of sequence of tenses as cases of wrong sequence of tense were not many. Setting, characterisation, and events in time were also handled correctly. However, it was exposed that students have problems with suspense and dialogue as only one of the sampled essays on narrative had suspense and none had a dialogue.

Concerning descriptive essays, it was found that students have difficulty writing descriptive paragraphs and essays. Thus only 1 participant has clear-cut descriptive features in his essay. The remaining essays were more of narrative than descriptive. Again, extensive usage of adjectives which is characteristic of descriptive composition was not many in the sampled texts.

On cause and effect essays, it was seen that students in private universities have control of cause and effect essays or paragraphs. This is because, $67 \%$ of the sampled essays on cause and effect were written dexterously, with the point-by-point style of writing dominating. 33\% of the students devoted a lot of time and space for the points on the causes of divorce to the neglect of the points on its effects. This created imbalance in the paragraphs of the composition.

The study also revealed that the participants can employ the techniques of argumentative adequately. But on comparison and contrast essays, it came to light that students have difficulty composing comparison and contrast essays or paragraphs.

\section{Discussions}

Essay writing on the various methods of development should aim at developing ideas 
on a given topic. In doing so, every assessor should ensure that students deploy the rudiments of such essays. For example, if one wants to narrate, one has to include the elements of narration in one's essay. Some of these elements are: sequence of tense, characters, plot, setting, events in time, and suspense. Failing to do this, one's essay will amount to a deviation of the method of development in question. This is to say that, the content and organisation of every write up are imperative constituents of methods of development. It will be out of place for a writer to narrate if he or she is expected to describe and vice versa. If a writer wants to describe appropriately, elements such as adjectives, and figurative expressions should be used. Sometimes, most writers focus their attention on the expression at the expense of the mechanical accuracy. Therefore, skillful writers should aim at striking a balance among these variables of content, organisation, expression, and mechanical accuracy.

\section{Conclusion}

The teaching and learning of methods of development in compositions of students who pursue various programmes at Business Departments of Private Universities have not been all that pronounced. It seems this subject matter has not been given the much needed attention as the course outlines from the two selected cases depict that methods of developing paragraphs have not been given separate sections. Apparently, the curriculum designers of English language related courses of Business Departments of these Private Universities have not given it a lot of attention for some reasons. One, maybe the business student is not a language student who has to study all the rudiments of English language and its related courses. Two, perhaps the business student has to be more proficient in business related courses. Some of the recommendations made are that a substantial attention should be given to the teaching and learning methods of development-description, comparison and contrast. Additionally, students should be assigned more essay-based tests on methods of development.

\section{References}

[1] Adams, K. and Keene, M. (2000) Research and Writing across the Disciplines. 2nd Edition, Mayfield Publishing Company, California.

[2] Dudley-Evans, A. and St. John, M.J. (1998) Developments in ESP: A Multi-Disciplinary Approach. Cambridge University Press, Cambridge.

[3] Al-Khasawneh, F.M.S. (2010) Writing for Academic Purposes: Problems Faced by Arab Postgraduate Students of the College of Business, UUM. ESP World, 9, 1-23. http://www.esp-world.infor

[4] Langan, J. (2001) College Writing Skills with Readings. 5th Edition, McGraw-Hill Companies Inc., New York.

[5] Buscemi, V.S. and Smith, C. (2000) 75 Readings Plus. 5th Edition, McGraw-Hill Company Limited, USA.

[6] Carroll, A.J., Wilson, E.E. and Forlini, G. (2001) Writing and Grammar: Communication in Action, Bronze Level. Prentice-Hall Inc., New Jersey.

[7] Seldess, J. (1996) How to Write a Descriptive Essay. 
www.writeexpress.com/descriptive-essay

[8] DiYanni, R. and Hoy II, C.P. (2005) Frames of Mind: A Rhetorical Reader with Occasions for Writing. Thomson Wadsworth, Massachusetts.

[9] Anderson, R., Brinnin, M.J., Leggett, J., Arpin, Q.G. and Toth, A.S. (1993) Elements of Literature: Literature of the United States, Fifth Course. Holt Rinehart Winston, Florida.

[10] Leake, J. and Knudsen, J. (2002) The Visual Guide to College Composition. Addison-Wesley Longman, Inc., New Jersey.

[11] Claudio, A.M. (2005) Comparison and Contrast Essay. www.1.uprh.edu/.../comparison\%20and\%20contrast $\% 20$ essay/.com

[12] www.freeessay.com/2009/11/comparisoncontrast-essay.html

[13] www.essaystart.com/kinds_of_essays/classification_essays.html

[14] James, M. and Merickel, A.P. (2002) Reading Literature and Writing Argument. Pearson Educational Inc., New Jersey.

Submit or recommend next manuscript to OALib Journal and we will provide best service for you:

- Publication frequency: Monthly

- 9 subject areas of science, technology and medicine

- Fair and rigorous peer-review system

- Fast publication process

- Article promotion in various social networking sites (LinkedIn, Facebook, Twitter, etc.)

- Maximum dissemination of your research work

Submit Your Paper Online: Click Here to Submit

Or Contact service@oalib.com 